\title{
Life History Proses Perubahan Diri Mantan Narapidana Residivis
}

\author{
Mega Kurnia Utama ${ }^{1}$, dan Damajanti Kusuma Dewi
}

Program Studi PsikologiUniversitas Negeri Surabaya,

\begin{abstract}
The processs of changes among ex-recidivist convict is interesting issues in terms of how they face problems of living with society that impact on self-change. The purpose of this study was to explore the experience of an ex-recidivist convict in struggling to reintegrate into society. This research used qualitative approach with life-history method. One participant who is an ex-recidivist convict and two significant others were involved in this study. Data collected using semi-structured interviews and analyzed using narrative analysis. This study reveals 4 (four) major themes, the participant's life before his change, the participant's self-transformation, the ways he takes to face the obstacles of change and social context of the changing process. In general, the result of this study shows that the participant has succeeded his changing process which is signed by the fact that he does not do any criminal acts or another negative behaviour anymore. The self-changing has been increased by the participant through his efforts to change his surrounding environment into the better condition.
\end{abstract}

Keywords: process, self-changing, ex- recidivist convict.

\begin{abstract}
Abstrak: Penelitian ini dilatarbelakangi oleh bagaimana proses perubahan mantan narapidana residivis baik dari segi permasalahan yang muncul serta dampak perubahan diri pada individu. Penelitian bertujuan mengungkap bagaimana pengalaman partisipan terkait proses perubahan, cara partisipan dalam menghadapi hambatan, serta keadaan lingkungan sosial pada proses perubahan. Penelitian menggunakan pendekatan kualitatif dengan metode life history dengan analisis data naratif. Pengambilan data menggunakan metode wawancara semi-tersturktur yang terdiri dari 1 partisipan inti dan 2 orang significant other. Peneltian menghasilkan 4 tema besar yaitu kehidupan partisipan sebelum berubah, proses perubahan diri, cara menghadapi hambatan, kondisi lingkungan sosial dalam proses perubahan. Hasil secara umum menunjukkan bahwa partisipan berhasil dalam proses perubahannya yang ditandai tidak kembali melakukan tindakan kriminal ataupun perilaku negatif lainnya. Perubahan diri juga partisipan tingkatkan dengan usahanya dalam mengubah lingkungan.
\end{abstract}

Kata Kunci: proses, perubahan diri, mantan narapidana residivis.

Narapidana merupakan seorang terdakwa yang telah terbukti bersalah karena melakukan tindak pidana dan dibatasi haknya sebagai warga negara di Lembaga Pemasya rakatan (Lapas) (UU No. 12 tahun 1995) Peran Lapas sendiri sudah diatur di dalam Pasal 2 UU No. 12 Tahun 1995 yaitu melindungi dan membina agar narapidana

Korespondensi tentang artikel ini dapat dialamatkan kepada Mega Kurnia Utama melalui email: oetama.mg@gmail.com 
menjadi manusia seutuhnya, menyadari kesalahan, memperbaiki diri, tidak mengulangi tindak pidana dan dapat diterima oleh lingkungan sosial. Narapidana di Jawa Timur sendiri bedasarkan data Direktorat Jenderal Pemasyarakatan (ditjenpas.go.id) per November 2014 menjelaskan bahwa ada 9.926 orang narapidana di Provinsi Jawa Timur. Kota Surabaya sendiri tercatat memiliki 1.236 orang.

Kebebasan merupakan hal yang paling ditunggu bagi para narapidana di lembaga pemasyarakatan. Martin (dalam Lee, 2012) yang merupakan Wakil Presiden dari Fortune Society mengatakan bahwa sebagian besar narapidana yang baru bebas memiliki semangat dan mereka berharap dapat kembali melakukan hal-hal yang lebih baik.

Kebebasan seseorang yang baru keluar dari lapas biasanya akan mengalami kesulitan dalam menyesuaikan diri terhadap lingkungan sosialnya. Karena adanya stigma dan diskriminasi dari masyarakat. Stigma dan diskriminasi yang diterima tidak hanya dirasakan oleh mantan narapidana, namun juga dapat mempengaruhi pihak keluarga individu tersebut (Thompson, 2008). Bentuk dari stigma dan diskriminasi yang muncul dapat berupa hilangnya kepercayaan terhadap mantan narapidana dalam berbagai hal, dikucilkan, perbedaan perlakuan yang biasanya merugikan mantan narapidana. Stigma yang diberikan lingkungan sosial terhadap mantan narapidana residivis akan lebih tinggi dan semakin kuat karena individu tersebut telah mengulangi perilaku yang melanggar hukum dan norma.

Dampak dari pemberian stigma dan label akan semakin memungkinkan mantan narapidana akan kembali melakukan tindakan kejahatan. Tekanan sosial yang cukup kuat akibat pemberian label kepada mantan narapidana akan membuat ketidaknyamanan pada individu tersebut. Ketidaknyamanan pada label yang diberikan akan semakin memperkuat individu untuk kembali melakukan pelanggaran dan atau kejahatan (Becker, dalam Nuraini dan Ahmadi, 2005).

Terdapat berbagai macam faktor yang menjadikan narapidana yang bukan residivis kembali mengulangi tindakan pidana. Muhlhausen (2010) mengungkapkan faktor tersebut adalah karaktersitik demografi, pengalaman kerja individu, riwayat pekerjaan, tingkat pendidikan, catatan kriminal dan penggunaan narkotika. Muhlausen (2010) juga menemukan bahwa adanya hubungan antara pekerjaan terhadap peningkatan kemungkinan seorang mantan narapidana dalam mengulang kejahatannya. Begitu juga dengan faktor tidak memiliki pekerjaan, dan perilaku kriminal diusia muda.

Mantan narapidana yang memiliki keinginan untuk berubah menjadi indvidu yang lebih baik akan cukup sulit karena adanya berbagai macam hambatan internal dan eksternal yang akan dihadapi. Hambatan Internal terdiri dari kurangnya kepercayaan diri, kurangnya pengetahuan tentang perubahan yang akan dipelajari, dan tidak berfungsinya sikap dalam menilai baik-buruknya suatu perilaku yang baru. Hambatan eksternal terdiri dari kurangnya dukungan yang dilakukan oleh orang-orang di sekitar individu yang mencoba untuk melakukan perubahan, berupa lingkungan sosial yang kurang percaya bahwa seseorang dapat mengubah diri menjadi lebih baik karena masih dipengaruhi oleh stigma yang melekat (Olson, 1992).

Kurt Lewin (dalam Russell \& Russell, 2005) menjelaskan perubahan terjadi karena adanya ketidakseimbangan antara kekuatan pendorong (driving force) dengan kekuatan penahan (restraining force). Perubahan terjadi ketika kekuatan pendorong lebih tinggi dibandingkan dengan kekuatan penahan. Pender (dalam Lubkin \& Larsen, 2006) menjelaskan mengenai kekuatan pendorong dan penghambat. Kekuatan pendorong terdiri dari individu memiliki motivasi yang kuat 
dari dalam diri untuk melakukan perubahan, lingkungan sosial yang mendukung, keadaan finansial, dan materi yang cukup. Faktor eksternal terdiri dari kurangnya fasilitas, materi, sumber keuangan serta kurangnya dukungan dari lingkungan sosial dalam melakukan proses perubahan. Faktor internal terdiri dari kurangnya pengetahuan mengenai perubahan yang akan dilakukan dan kurangnya motivasi dari dalam diri untuk melakukan perubahan.

Tahapan mengenai proses perubahan akan penulis jelaskan bedasarkan teori yang dikemukakan oleh Prochaska \& DiClemente (1992) yang terdiri dari 5 tahapan, yaitu pra-kontemplasi, kontemplasi, persiapan, aksi dan perbaikan. Tahap Pra-kontemplasi menjelaskan bahwa pada tahap ini belum munculnya keinginan individu untuk melakukan perubahan diri. Tahap Kontemplasi merupakan tahap dimana telah munculnya kesadaran akan suatu permasalahan, namun belum adanya keinginan untuk melakukan suatu perubahan. Tahapan ketiga yaitu Persiapan, pada tahap ini menjelaskan bahwa individu telah memulai langkah-langkah awal untuk melakukan persiapan untuk melakukan perubahan diri. Tahap aksi yang merupakan tahapan selanjutnya menjelaskan bahwa individu sedang melakukan proses perubahan secara menyeluruh terhadap perilaku, kebiasaan dan pengalaman. Tahap terakhir adalah Pemeliharaan, individu pada tahap ini telah berhasil melakukan perubahan pada dirinya dan akan melakukan pemeliharaan yang bertujuan untuk mencegah kembali kepada perilaku yang lama dan untuk memperkuat dampak positif yang dirasakan pada perubahan yang terjadi.

Fokus yang diambil pada penelitian akan lebih kepada bagaimana pengalaman partisipan terkait dengan proses perubahan diri partisipan, cara partisipan dalam melalui hambatan-hambatan yang dialami, cara partisipan dalam melalui hambatan- hambatan yang dialami. Pembahasan mengenai bagaimana pengalaman Bapak Budi ketika melakukan proses perubahan diri akan lebih banyak dikaji dalam penelitian ini. Hal ini lah yang membedakan penelitian ini dengan penelitian-penelitian sebelumnya.

Bedasarkan penjelasan diatas, peneliti tertarik dalam mengungkapkan bagaimana pengalaman partisipan dalam proses perubahan, dalam lingkungan sosial seperti apa partisipan mengubah dirinya, dan strategi dalam menghadapi hambatan. Sehingga hal tersebut menjadikan alasan peneliti dalam melakukan penelitian mengenai proses perubahan mantan narapidana residivis.

\section{Metode}

Pendekatan yang digunakan dalam penelitian ini adalah model Life History. Life History merupakan suatu model yang berbasis wawancara dan percakapan, bertujuan untuk menghasilkan penggambaran yang dalam dan analisis yang kompleks mengenai kehidupan atau pengalaman hidup secara menyeluruh atau pada aspek-aspek tertentu terhadap hidup seseorang dengan menggunakan metode naratif.

Partisipan pada penelitian ini sebanyak 1 orang yang bernama Bapak Budi (bukan nama sebenarnya). Bapak Budi saat ini berusia 60 tahun dan bertempat tinggal di kawasan Rangkah, Surabaya. Secara fisik, Bapak Budi terlihat cukup sehat dan bugar.

Teknik pengumpulan data dalam penelitian ini menggunakan teknik wawancara dan pengumpulan data. Wawancara yang dilakukan adalah wawancara semi terstruktur. Instrumen yang digunakan adalah pedoman wawancara dan alat perekam untuk wawancara. Data sekunder diambil dari wawancara partisipan melalui pihak kedua. Uji keabsahan data menggunakan validitas 
triangulasi data. Pada peneltiian ini triangulasi data diambil dari 2 significant other yaitu anak perempuan partisipan dan teman masa kecil partisipan. Significant Other pertama adalah teman masa kecil partisipan yang bertempat tinggal tepat dibelakang rumah partisipan yaitu didaerah Rangkah, Surabaya. Significant Other kedua pada penelitian ini merupakan anak perempuan partisipan yang membuka usaha didekat rumah partisipan.

\section{Hasil}

Penelitian ini bertujuan untuk mengungkapkan bagaimana pengalaman partisipan dalam proses perubahannya, strategi dalam menghadapi hambatan, dan dalam kondisi lingkungan sosial yang bagaimana partisipan melakukan proses perubahan dirinya. Hasil ini akan dibahas melui 4 tema yaitu (1) Kehidupan Partisipan Sebelum Berubah, (2) Proses Perubahan Diri, (3) Cara Menghadapi Hambatan, (4) Kondisi Lingkungan Sosial dalam Proses Perubahan.

\section{Tema 1: Kehidupan Partisipan Sebelum Berubah}

a. Kehidupan masa kecil

Partisipan mengaku sering tidak masuk sekolah yang mengakibatkan dirinya sering menerima kekerasan dari orang tuanya. Puncaknya partisipan disuruh pergi dari rumah oleh orang tuanya. Meski hanya sekedar omongan namun partisipan memilih untuk keluar dari rumah.

"[...] saya sering dicambuk, dicambuk orang tua saya dan tau-tau orang tua saya bilang "kamu kalau bisa jadi berandal kalau kamu gak mau sekolah!." Gitu” (P1-H-W1-B10)

"Iya diusir, sebenarnya pura-pura aja orang tua saya tapi ternyata kami langsung pergi aja." (P1-H-W1-B14)
Hal ini didukung oleh pernyataan dari teman masa kecil partisipan selaku significant other yaitu bapak S.

\section{"[...] Waktu sekitar umur 12 tahun dia lari ke Surabaya diusir sama orang tuanya[...]" (SO1-S-W1-B23)}

Selama berada di Surabaya partisipan mengaku menjadi gelandangan sendirian. Pada akhirnya partisipan diasuh, dibina oleh orang tua angkat yang berprofesi sebagai pemulung dan menderita penyakit lepra. Selama bersama orang tua angkatnya, partisipan mengaku hidup serba kekurangan.

"[...] Jadi kami dibina oleh orang yang terkena penyakit kusta, yang laki-laki bernama Bang $L$ dan yang perempuan Mbok N. Jari-jarinya udah abis semua. Kami dibina oleh orang kusta, dinasehati dan kami disuruh sekolah." (P1-H-W1B22)

"[...] Kami ngelap sepeda, terus kalau ada sisa-sisa orang-orang yang makan gak habis ya tak kumpulkan terus saya bawa ke ibu angkat saya terus ya dimakan bertiga." (P1-H-W1-B41)

Pengalaman partisipan juga diperkuat dengan pernyataan dari anak partisipan yaitu ibu S selaku significant other 2.

"[...]Terus ikut orang yang terkena penyakit lepra. Jadi dari kecil sudah diasuh dengan orang lepra dan tidurnya dulu ya dimakam [...] ", (SO2-S-W1-B10)

b. Awal masuk dunia kriminal

Partisipan mulai melakukan pencurian ketika masih berumur 14 tahun. Mulai mengenal perilaku tersebut karena ajakan teman-teman sebayanya pada waktu itu. Alasan Partisipan melakukan pencurian adalah karena faktor ekonomi. 
"[...] sekitar umur 14 tahun kami baru, baru mengenal teman dan diajak ke ummm... mengambil anak timbal (pemberat untuk timbangan) di Kapas Krampung [...]” (P1-H-W1-B47

Partisipan mengatakan bahwa ketika mulai mencuri, beliau pun berkata cukup senang dalam melakukan pencurian. Alasannya karena beliau anggap hal tersebut cukup gampang dilakukan.

"[...] Sering sekali kita ambil (anak timbal), saya kira perbuatan yang tidak baik itu enak dan gampang dilakukan. Terus.. ya gak tak makan sendiri (hasil mencuri anak timbal).”(P1-H-W1-B53)

\section{c. Terjun di dunia kriminal}

Pencurian yang dilakukan partisipan sejak umur 14 tahun mengakibatkan partisipan ditangkap polisi. Partisipan mengaku dijebak polisi saat melakukan pencurian dan masuk kedalam lapas pada saat remaja

\section{"[...] adanya dari temen ya seandai kata mas mencuri, saya ini orang-orangnya (orang suruhan) polisi, (menirukan dialog) "Itu loh, orang yang berbuat (kejahatan) itu disana, disana dan disana, lalu tidurnya disini)." Jadi mas saya ajak ngobrol tau-tau mas ketangkap polisi, jadi saya (orang suruhan polisi) berpura pura tidak tahu padahal saya yang beritahu polisi kalau mas ini yang mencuri." (P1-H-W2-B10).}

Tidak ada rencana partisipan untuk berhenti meskipun sudah masuk lapas. Partisipan terus melakukan pencurian sesaat setelah bebas dari lapas. Seringnya melakukan pencurian mengakibatkan partisipan berkali-kali keluar masuk lapas.

"[...] Habis gitu kok saya merasa enak dan kami terus melakukan itu (mencuri) terus dan sampai kami dihukum (dipenjara) satu tahun terus pulang dan berbuat lagi (mencuri)" (P1-H-W1-B80)
"Ya kurang lebih sudah 6 kali dipenjara sampai dari nusakambangan." (P1-HW2-B19)

Hal senada juga dikatakan oleh Bapak S selaku significant other 1 mengenaii pengalaman partisipan terkait keluar masuk lapas.

“[...] sering keluar masuk (LP) kurang lebih itu sekitar 7 kali kalau saya tidak salah itu." (SO1-S-W1-B19)

Alasan partisipan tetap bertahan dalam melakukan pencurian meskipun telah masuk lapas berkali-kali karena beberapa hal. Alasannya adalah kebutuhan hidup, untuk bersenang-senang, keinginan menolong orang yang tidak mampu serta permasalahan ekonomi lainnya.

"[...] karena kami masih mau mengejar ekonomi, mengejar ekonomi dan sebagainya. Untuk.... Untuk masa depan anak dan istri sampai kami bisa melakukan perbuatan semacam itu. kan karena sebenarnya saya ingin kaya. [...]", (P1-H-W2-B154)

[...](hasil) perbuatan jahat saya untuk nafkah kepada orang-orang yang membutuhkan dan untuk pribadi ya untuk minum, judi melacur dan sebagainya (suara menurun)." (P1-H-W2-B124)

"Dari segi ekonomi ya kurang makan kek, banyak terjebak dari uang renternir lah ya macem-macem. [...]" (P1-H-W1B503)

Alasan kenapa partisipan membagikan hasil mencurinya kepada orang yang membutuhkan adalah merasa ada hutang budi dengan orang tuanya yang sudah meninggal.

"Ya juga pun saya sudah ditolong sama orang (suara sedikit meninggi), orang yang sudah menolong saya belum sempat merasakan hasil saya jadi kami 
sebaliknya membantu orang." (P1-HW1-B510)

d. Kehidupan Partisipan Saat di Lembaga Pemasyarakatan

Partisipan selalu mendapatkan siksaan dari polisi ketika baru saja dimasukkan kedalam lapas. Kehidupan partisipan lainnya adalah partisipan diberikan berbagai bentuk pelatihan keterampilan dari pihak lapas.

"Ya memang perasaan pertama kali dipenjara itu kan harus dipukuli kan sama polisi [...]. (P1-H-W2-B119)

"Saya di penjara mulai dari Kalisosok sampai Nusakambangan itu kami bikin kerajinan tangan seperti sabuk dari kayu, seperti kapal-kapalan yang dimasukkan di dalam botol, seperti patung yang dibuat dari kertas. Itu kegiatan saya, sebab tidak ada kegiatan selain membuat keterampilan itu sendiri." (P1-H-W1B497)

\section{e. Hubungan dengan keluarga}

Hubungan partisipan dengan keluarga meliputi hubungan dengan istri sebelumnya dan keluarga kandungnya. Istri partisipan bersikap apatis terhadap perilaku mencuri partisipan. Asalkan kebutuhan keluarga terpenuhi, istri partisipan tidak mempermasalahkan sumber penghasilan partisipan

"Kalau istri saya yang pertama sih senang aja asal dapat uang gitu, masa bodoh. Ya seperti gini lah mas (menunjuk penulis), seperti mas punya istri terus ada tetangga pakai perhiasan dan mas pegawai kantor [...]" (P1-H-W1-B536)

Keluarga kandung partisipan juga sebagian besar bersikap kurang peduli. Jarang melihat keadaan partisipan dan kurang perhatiannya keluarga partisipan terhadap partisipan dan keluarganya adalah gambaran hubungan partisipan dengan keluarganya.

"Ya kebetulan orang tua saya ya masa bodoh, dan saya juga tidak pernah makan dari nasi orang tua dan orang tua juga tidak mau menerima uang dari saya dari perbuatan mencuri [...]" (P1-H-W2B113)

Significant other 1 dan 2 juga memperkuat pernyataan partisipan mengenai hubungan partisipan dengan keluarganya.

"Ya kalau hubungan dengan keluarga kandung bapak itu bisa dibilang kurang baik, ya yang gak pernah kesini ya gak pernah lihat bapak $H$ itu bagaimana biarpun bapak itu dipenjara gak ada saudara-saudara dan keponakankeponakannya bapak yang melihat bapak pada waktu itu. [...]" (SO2-S-W1-B126)

"[...] gini loh ceritanya... Seperti gak punya saudara gak punya apa-apa. Kan dia lari dari orang tuanya terus hampirhampir sudah dewasa dia ketemu lagi. [...]" (SO1-S-W1-B35)

\section{f. Kejadian yang berpengaruh}

Subtema ini membahas mengenai kejadiankejadian yang mempengaruhi kehidupan partisipan. Kejadian tersebut adalah orang tua angkat meninggal, terpaksa menikah, dan ditinggal istri untuk menikah lagi. Orang tua angkat partisipan meninggal saat partisipan masih diusia remaja. Sebelum meninggal orang tua angkat partisipan berpesan pada partisipan agar kelak partisipan harus menjadi pemimpin masyarakat miskin.

"[...] malamnya sebelum meninggal dia bilang sama saya "Kamu kalau sudah besar harus menjadi pemimpin orangorang bambung (masyarakat miskin seperti gelandangan, pengemis dan lainnya)." Sesudah itu dia meninggal dan memeluk saya [...]"'(P1-H-W1-B61) 
Partisipan menikahi istrinya pada saat itu karena terpaksa. Paksaan orang tua kandung dan karena hamil diluar nikah menyebabkan partisipan menikahinya meskipun pada waktu itu ada rasa khawatir mengenai cara beliau untuk memberikan nafkah.

“[...] Ketemu orang tua kandung saya lalu kami disuruh nikah. "Untuk nikah dimakanin apa (istri saya)?" kata saya gitu.”(P1-H-W1-B100)

"[...]Ya.... Saya sama orang tua saya kan dipaksa untuk menikah supaya perbuatan jahat itu tidak terulang-ulang lagi, dan saya waktu itu ketemu orang tua saya dan diajak untuk menikah sama yang namanya $\mathrm{S} . "(\mathrm{P} 1-\mathrm{H}-\mathrm{W} 2-\mathrm{B} 2 \mathrm{l})$

"[...]Ya berhubung istri saya yang pertama suka dengan saya dan juga beliau itu hamil, hamil sebelum menikah [...]" (P1-H-W2-B27)

Ketika beliau masuk lapas karena mencuri untuk memenuhi kebutuhan hidup keluarganya. Istrinya memutuskan untuk pergi meninggalkan partisipan dan menikahi orang lain.

"[...]pulang dari Nusa Kambangan istri saya diambil orang [...]" (P1-H-W1B116)

Pernyataan partisipan juga diperkuat dengan pernyataan kedua significant other.

"Ya pada waktu itu ya istri pertama ya biasa aja mas, tapi pada akhirnya ya dibawa lari sama orang. . Kan biasa lah mas faktor ekonomi, kan yang ngebawa lari ya orangnya berkecukupan [...]" (SO1-S-W1-B76)

"[...]ketika itu Bapak $H$ dipenjara dan istrinya dibawa lari orang [...]" (SO1-SW1-B12)

\section{Tema 2: Proses Perubahan Partisipan}

a. Munculnya keinginan berubah

Munculnya keinginan partisipan untuk melakukan perubahan adalah karena beberapa faktor. Faktor tersebut adalah partisipan merasa cukup dengan siksaan yang didapat selama di lapas dan hal itu semakin diperkuat ketika istrinya pada waktu itu memintanya untuk berhenti mencuri sebelum menikahinya. Faktor lainnya adalah nasehat dari salah satu kakak kandung partisipan

"Ya..... Apa ya (berfikir) ya waktu itu saya sudah merasakan pukulan-pukulan yang keras dan sudah merasakan apa yang tidak diinginkan [...]" (P1-H-W2B48)

"[...] Istri saya (yang sekarang) bilang "Aku mau menikah tapi kamu jangan berbuat jahat. Aku ga suka uang haram." Katanya, ternyata sudah ke tujuh kalinya memang saya sudah sadar. [...]" (P1-HW1-B117)

"[...] saya dinasehati oleh mas saya yang sekarang sudah almarhum kalau saya jangan sering beurusan dengan polisi, masa dari istri pertama sampai yang kedua masih memiliki urusan perbuatan dengan polisi yang akhirnya membuat saya malu, [...]" (P1-H-W2-B100)

Pernyataan partisipan juga diperkuat dengan pernyataan signifivant other 2 yaitu ibu $\mathrm{S}$.

"Hem... waktu itu bapak H keluar dari penjara dan tidak punya istri, ibu $M$ ini mau dinikahi. Ya biasa mas, yang penting bapak $H$ mau tobat. [...]" (SO1-S-W1B98)

b. Perubahan yang diinginkan

Partisipan ingin mengubah dirinya menjadi lebih baik. Bentuk perubahan yang diingin- 
kan adalah ingin menjadi orang normal yang tidak kembali menjadi narapidana dan tetap ingin dapat menolong orang yang tidak mampu.

"[...] Jadi poinnya itu jadi kami harus bisa menyadarkan diri, harus bisa berubah, jadi kami harus bisa membantu sama orang-orang yang membutuhkan." (P1-H-W2-B149)

Sama halnya dengan pernyataan kedua significant other mengenai perubahan yang partisipan inginkan.

"Ya pengen seperti orang normal dikampung-kampung mas, tidak ingin keluar masuk penjara lagi, begitu." (SO1-S-W1-B126)

"Bapak $H$ ingin orang-orang sini maju aja mas, ya gak seperti dulu lagi. Ingin menjadikan lingkungan yang aman, gak ada seperti dulu lagi. [...]" (SO1-S-W1B137)

\section{c. Alasan ingin berubah}

Partisipan memiliki beberapa alasan dalam melakukan perubahan diri. Alasan tersebut adalah karena keluarga, merasa berdosa, dan sudah merasa cukup dalam menerima hukuman. Faktor keluarga merupakan alasan partisipan ingin mengubah dirinya. Keinginan partisipan untuk mendidik istri dan anaknya agar menjadi pribadi yang lebih baik sehingga peristiwa seperti yang partisipan alami tidak akan terulang kembali pada anak dan cucunya.

"[...] karena anak-anak saya kami bisa berbangkit pikiran dan kami harus bisa berubah apalagi anak-anak saya semuanya perempuan [...]" (P1-H-W2B87)

"Ya pokoknya anak-anak saya jangan sampai terpengaruh! (suara tinggi). Takutnya nanti anak-anak saya mengatakan kepada saya terjadi nanti suaminya kelak mempunyai perbuatan sewenang-wenang [...]." (P1-H-W2-

B82)

Hal ini juga didukung oleh pernyataan dari anak partisipan selaku significant other 2 mengenai alasan partisipan.

"[...] demi anak dan istrinya bapak bisa berubah biar ada penilain sama cucucucunya supaya ada yang bisa dibanggakan seperti "Ini loh kakek saya, biarpun keluar dari penjara 8 kali tapi dia bisa berubah baik mengubah diri maupun mengubah warganya menjadi lebih baik." (SO2-S-W1-B60)

Partisipan juga merasa berdosa atas perilaku-perilakunya sebelum melakukan perubahan. Hal ini membuat partisipan berharap dengan mengubah dirinya beliau dapat membayar dosa-dosa atas apa yang telah beliau lakukan kepada Tuhan. Partisipan juga merasa sudah cukup dengan siksaan yang pernah didapatnya didalam lapas.

"Sebab kami mantan narapidana 8 kali juga kami mempunyai dosa-dosa yang besar saya ingin memberikan saya..... diterima atau tidak saya akan serahkan kepada yang maha atas [...]" (P1-H-W1B424)

"[...] Dan kami juga sudah merasakan seтиa kaki pejabat sudah pernah dipunggung dan perut saya. Mulai dari hansip sampai polisi. Waktu itu kami juga sudah merasakan pukulan-pukulan yang berat. [...]" (P1-H-WS1-B59

d. Wujud nyata usaha untuk berubah

Wujud nyata perubahan yang partisipan lakukan bermacam-macam. Awal perubahan partisipan diwarnai dengan partisipan mulai bekerja serabutan hingga merantau keluar Pulau Jawa bersama istrinya saat ini.

"[...] Juga kami sudah sadar, kerja pemulung. Jadi kami juga merasakan 
bagaimana orang mencari uang dengan keringat dan juga bagaimana orang mencari uang cuman dari harta kekayaan orang [...]. . (P1-H-W1-B578)

"[...] Kami bekerja dan sebagainya lah, sesudah itu kami merantau sampai di Sumatera, Palembang sampai Lampung sama istri saya jadi kami untuk uang yang halal." (P1-H-W1-B121)

Hal itu juga dibenarkan oleh significant other 1 mengenai kerja serabutan yang dilakukan partisipan.

"[...] Lalu bapak H taubat dan mencari rongsokan (pemulung) ini mas seperti saya pada waktu itu. kesehariannya ya kalau pagi ya menjadi pemulung kalau malam ya narik becak." (SO1-S-W1B100)

Keinginannya untuk menolong orang lain partisipan wujudkan dengan membentuk berbagai fasilitas warga. Fasilitasnya antara lain membentuk pengajian ibu-ibu, taman baca masyarakat, bimbingan belajar, dan sekolah gratis untuk anak-anak disekitar tempat tinggalnya.

\section{“[...] Kami menyusun ibu-ibu, saya kumpulkan ibu-ibu (menirukan dialognya) "bagaimana andaikata ibu- ibu ini saya ajak untuk kebaikan seperti pengajian di kampung-kampung lain?" ibu-ibu bilang "ya mau." [...]" (P1-H- W1-B178)}

"Ya ada bimbel untuk pendidikan dan perpustakan. Awal-awalnya ya kami tidak ingin membuka perpustakaan. Daripada anak-anak disini mondar-mandir jadi kami minta buku-buku dari anak-anak yang sudah lulus daripada buku-buku ditimbang (untuk dijual) mending saya kumpulkan untuk bacaan anak-anak, [...]" (P1-H-W1-B307)

"[...] liat aja SMPN 18 itu kami terbuka dan itu negeri bu, tanpa dipungut biaya dia (anak-anak) berangkat sekolah telanjang, pulang sudah pakai seragam, perlengkapan buku atau apapun sudah dicukupi [...]" (P1-H-W1-B345)

Significant other 1 juga memperkuat pernyataan partisipan mengenai hal ini.

"[...] dulu kan disini banyak WTS (Wanita Tuna Susila) mas. Jadi didirikan pengajian sama bapak $H$ untuk menjadi orang yang baik." (SO1-S-W1-B139)

Partisipan juga meminta salah satu yayasan yang ingin membangunkan partisipan rumah untuk diubah menjadi kamar mandi umum. Alasannya karena partisipan melihat banyak warganya yang tidak memiliki toilet dirumahnya.

\section{"[...] Kami diberi rumah, kami tidak membanggakan agama tapi kami membanggakan manusia ya mas. Jadi beliau saya tolak, jadikan tempat tidur saya (rumah yang mau dikasih) itu 4 MCK, apa itu MCK? Toilet. Sebelum orang-orang saya tidur di rumah, saya tidak mau tidur di rumah [...]" (P1-H- W1-B624)}

\section{e. Hambatan yang muncul}

Hambatan yang muncul terdiri dari hambatan eksternal dan internal. Hambatan internal datang dari diri partisipan dan hambatan eksternal datang dari luar diri partisipan.

Partisipan ketika memasuki awal perubahan masih mengkonsumsi minuman berakohol meskipun sudah berhentu untuk mencuri. Partisipan juga ketika masih memasuki awal perubahan partisipan masih memiliki pandangan bahwa harta orang lain merupakan harta miliknya.

"[...] istri saya pada waktu itu menasehati gitu kamipun tidak mau untuk.... Untuk berhenti begitu, tetap kali minum-minum [...]" (P1-H-W2-B84)

"[...] Demi keluarga selama ini. Kami juga bekerja dibengkel bubut dan kami 
kan masih mempunyai sifat bahwa harta kekayaan orang itu adalah milik saya [...]” (P1-H-W2-B68)

Hambatan eksternal muncul dari berbagai pihak, salah satunya adalah teman lama partisipan. Partisipan mengatakan temantemannya yang dulu masih mengajaknya untuk kembali melakukan pencurian

"Ya tidak juga, teman-teman ya pasti menyerang dan mengajak tapi saya tidak mau. Ya mengajak untuk mencari uang (haram)." (P1-H-W2-B148)

Hambatan eksternal yang lain saat partisipan ingin mengubah lingkungan sosialnya. Provokasi dari ketua RT agar warganya tidak mempercayai partisipan telah partisipan dapatkan. Warga yang lain juga memprovokasi warga lainnya bahwa partisipan hanya mengambil keuntungan dari bantuan yang diterima untuk usahanya mengubah lingkungannya.

"[...] Kata pak RT "Wah, itu tidak usah dipercaya dia sama-sama orang yang gak baik jadi gak mungkin baik." Ternyata buyar (pengajiannya) [...]" (P1-H-W1B168)

"Ya cuman senyumnya senyum sinis atau ya juga banyak...... um... kalau ada bantuan mereka bilang "enak ya pak $H$ selalu dapat dua tapi semuanya satu." Itu sering banyak orang yang mencaci maki semacam itu." (P1-H-W1-B474)

Proses perubahan partisipan juga diwarnai dengan berbagai bentuk respon dari temannya. Banyak dari teman-temannya yang mengatakan bahwa partisipan saat ini sudah menjadi alim, tidak seperti dulu lagi.

$$
\begin{aligned}
& \text { "[...] ya teman-teman sempat heran } \\
& \text { seperti (menirukan dialog) "Cie, } \\
& \text { sekarang sudah tidak melakukan } \\
& \text { perbuatan yang tidak diinginkan (suara } \\
& \text { pelan)." Jadi perbuatan-perbuatan yang } \\
& \text { tidak diinginkan itu ya sudah saya }
\end{aligned}
$$

pendam lah istilahnya." (P1-H-W2B124)

"Ya memang manusia itu banyak rintangan lah mas, banyak rintangan. Jadi kami untuk kebaikan itu maupun dari penjudi, peminum dan sebagainya, teman-teman mengatakan "Wih, kamu sekarang sudah menjadi seperti kiai ya, orang alim. " [...] "(P1-H-W2-B163)

\section{Tema 3: Cara Menghadapi Hambatan}

a. Cara partisipan melalui hambatan

Partisipan tetap bangkit meskipun berbagai kegagalan terjadi. Partisipan juga tidak peduli dengan apa yang dikatakan masyarakat mengenai dirinya.

"Ya kami maju terus, untuk demi kebaikan. Sesuai dengan tema saya yaitu Demi Anak dan Istri Aku akan Bertaubat Selamanya. Jadi tato saya ini ada kisah yaitu demi anak dan istriku aku akan bertaubat selamanya. [...]" (P1-H-W1B484)

Significant other 1 juga menguatkan pernyataan partisipan tentang tidak menyerah dan tetap bangkit.

"Ya berjuang sedikit demi sedikit mas, awal-awalnya males mas orang-orang itu tapi akhirnya ya bapak sudah terbiasa menghadapi kayak gitu mas. Ya cuek aja mas kalau ada omongan-omongan yang kurang enak ya wes biasa mas, gak direken (tidak dipedulikan) yang penting dia itu mengajak baik-baik supaya bisa baik, gak dihiraukan kalau ada orang bilang apa yo wis." (SO1-S-W1-B171)

Partisipan menghadapi hambatannya juga ditunjukkan dengan cara menghindari ajakan teman-temannya. Penolakkan secara halus juga partisipan lakukan pada kasus ini.

"Ya.... Kalau anak-anak (teman-teman) punya acara minum ya kami hanya tunduk kepala aja tidak menengok kanan 
dan kiri. Pura-pura kami tidak tahu. [...]" (P1-H-W2-B171)

"[...] kalau kami dipanggil ya saya datangi, kalau saya ada rokok ya saya kasih rokok dengan alasan kami barusan ngobat kan gitu. [...]” (P1-H-W2-B174)

Keluarga merupakan faktor yang mempengaruhi bagaimana partisipan bisa menghadapi hambatan-hambatan yang muncul pada proses perubahannya. Partisipan meminta keluarganya untuk mendukung dan mendoakannya dalam proses perubahannya. Tidak hanya meminta dukungan dari keluarga, namun partisipan juga menjadikan keluarga sebagai motivasinya saat partisipan mengalami rasa putus asa.

"[...] bapak sebelumnya bilang "saya ingin berubah supaya enggak seperti ini." "Ya enggak apa-apa asalkan bapak mau untuk berubah." Lalu bapak bilang "saya ingin mengubah satu diri saya dan kedua adalah warga saya agar menjadi lebih baik seperti mantan WTS juga ingin saya ubah." Terus ibu ya bilang "Ya gak apa-apa kalau bapak mau berubah seperti itu dan kalau bapak sanggup." "saya Insyaallah sanggup kalau ada dukungan dari anak dan istri dan orang tua." Bapak bilang seperti itu mas. [...]" (SO2-S-W1-B43)

"Sering dinasehati seperti itu dan sebagainya dan ternyata karena anakanak saya kami bisa berbangkit pikiran dan kami harus bisa berubah apalagi anak-anak saya semuanya perempuan" (P1-H-W2-B87)

\section{Tema 4: Kondisi Lingkungan Sosial dalam Proses Perubahan}

a. Kondisi Lingkungan Masyarakat

Partisipan sejak awal berada di Surabaya hingga memutuskan untuk berubah berada dilingkungan sosial yang kurang sehat. Kemiskinan, perilaku negatif masyarakat- nya seperti mabuk-mabukan, narkoba, pencuri, dan WTS (Wanita Tuna Susila).

"[...] Disini kan tempat para pelacur semua, wanita penghibur, tempat judi, tempat mabuk-mabukan dan juga saya pun dulu berbuat semacam itu. [...] " (P1H-W1-165)

Begitu juga dengan pernyataan dari kedua significant other mengenai kondisi lingkungan sosial terkait proses perubahan partisipan.

"Yo ruwet mas kampung kene disik iku (Ya rumit mas kondisi kampung ini waktu dulu), Yah bagaimana yah banyak yang dulu bekas orang gak karu-karuan (yang gak benar) mas, seperti WTS, gelandangan, pemabuk, yah gitu lah mas. " (SO1-S-W1-B178)

"Ya dulunya ya masyarakat disini ya kerjaannya ya kebanyakan WTS, keluar malam, keluar malam ya gitu aja." (SO2S-W1-B72)

Gambaran mengenai masyarakat di lingkungan baru terlihat kurang mendukung partisipan saat partisipan ingin mengubah lingkungannya. Provokasi dari ketua RT dan dari pihak warga lain mempengaruhi lainnya yang kemudian menyebabkan masyarakat kurang percaya terhadap partisipan dalam proses perubahan dirinya.

"[...] Kata pak RT "Wah, itu tidak usah dipercaya dia sama-sama orang yang gak baik jadi gak mungkin baik." Ternyata buyar (pengajiannya) [...]" (P1-H-W1B168)

"[...] Ternyata ibu-ibu itu dikacau lagi sama RT itu sama **** (sebut nama) dia bilang "itu gak mungkin dikasihkan (bajunya), pasti itu mau dijual untuk gini gini gini gini.” [...]” (P1-H-W1-B241)

b. Kondisi Lingkungan Keluarga

Lingkungan keluarga merupakan lingkungan yang mempengaruhi partisipan 
dalam proses perubahannya. Partisipan berhenti mencuri saat beliau menikah lagi dan ingin membangun keluarganya.

"kami harus bisa ee..... apa itu.... (jeda 2 detik) harus bisa menerima hasil dari Allah saja, dari Tuhan saja. Berani tak nikah (istri yang sekarang) saya harus berhenti berbuat jahat." (P1-H-W1B551)

"[...] baru kami menikah kedua kalinya istri saya yang sekarang. Istri saya (yang sekarang) bilang "Aku mau menikah tapi kamu jangan berbuat jahat. Aku ga suka uang haram." Katanya, [...]" (P1-H-W1B117)

Pernyataan significant other 1 juga memperkuat mengenai apa yang partisipan katakana.

"[...] waktu itu bapak $H$ keluar dari penjara dan tidak punya istri, ibu $M$ ini mau dinikahi. Ya biasa mas, yang penting bapak H mau tobat. Lalu bapak H taubat dan mencari rongsokan (pemulung) ini mas seperti saya pada waktu itu. [...]", (SO1-S-W1-B98)

Keluarga juga mempengaruhi dalam proses perubahan partisipan. Pengaruh tersebut terlihat dari bagaimana keluarga membantu partisipan dengan selalu mengingatkan untuk berhenti mengkonsumsi alkohol dan perbuatan yang kurang baik lainnya.

"[...] kami kan masih mempunyai sifat bahwa harta kekayaan orang itu adalah milik saya jadi istri saya tidak mau dan kami harus kerja yang jujur [...]" (P1-HW2-B69)

"Kalau anak dan istri saya memang melarang jangan sering-sering mempunyai perbuatan begitu, minumminum dan sebagainya [...]" (P1-H-W2B81)

\section{Pembahasan}

Perubahan diri seseorang muncul karena kekuatan pendorong yang lebih besar daripada kekuatan penahan (Lewin, dalam Russell, 2006). Prochaska \& DiClemente (1992) menjelaskan bahwa proses perubahan seseorang itu melalui 5 tahap yaitu Prakontemplasi, Kontemplasi, Persiapan, Aksi, dan Pemeliharaan.

Kehidupan partisipan diawali dengan partisipan yang memutuskan untuk pergi dari rumahnya di Madura menuju Surabaya ketika partisipan berumur 12 tahun. Hal ini terjadi karena partisipan sering mendapatkan siksaan dari ayahnya akibat dari seringnya partisipan membolos dari sekolahnya dan mengaji.

Partisipan saat berada di Surabaya tinggal dilingkungan yang sebagian besar adalah gelandangan. Tidak lama setelah itu partisipan diangakat anak oleh pasangan suami istri yang berprofesi sebagai pemulung yang kemudian diberikan pendidikan dan diasuh. Partisipan selama tinggal di Surabaya berada dalam kondisi keluarga yang miskin. Kondisi kemiskinan ini yang membawa partisipan kedalam dunia kriminal.

Awal mula partisipan memasuki dunia kriminal saat berumur kurang dari 14 tahun. Partisipan yang diajak temannya untuk mencuri anak timbangan dipasar. Partisipan melakukan pencurian karena keinginannya untuk membantu ekonomi didalam keluarga angkatnya. Penjelasan Rhee \& Waldman (dalam Jones, 2005) menyatakan bahwa bahwa lingkungan merupakan faktor yang paling penting dalam perilaku remaja. Begitu juga dengan partisipan yang tinggal dalam kondisi keluarga yang miskin dan teman-temannya yang mengajak partisipan mencuri anak timbangan.

Perilaku kriminal partisipan menjadikan partisipan berkali-kali keluar masuk kedalam lapas yang kasusnya sebagian besar adalah pencurian. Pertama kali partisipan masuk kedalam lapas adalah pada tahun 1964 atau ketika partisipan masih berumur kurang dari 14 tahun. Beberapa kali masuk kedalam lapas dan 
hinngga pada 1998 ketika partisipan dibebaskan dari lapas di Nusakambangan dan memutuskan untuk melakukan perubahan.

Partisipan memiliki kejadian yang berpengaruh selama periode tersebut. Ibu angkat partisipan pada waktu itu meninggal dunia ketika partisipan masih berumur 15 tahun dan sebelum meninggal ibu angkat partisipan memberikan pesan kepada partisipan bahwa partisipan harus menjadi pemimpin masyarakat miskin. Tidak lama setelah ibu angkat partisipan meninggal, ayah angkat partisipan juga meninggal dunia.

Kejadian yang lainnya adalah partisipan yang terpaksa menikah. Hal ini terjadi karena paksaan dari orang tua dan karena calon istri partisipan yang telah hamil diluar nikah. Partisipan yang terpaksa menyanggupi munculnya kebingungan untuk menafkahi keluarganya, akhirnya partisipan kembali melakukan pencurian. Pencurian tersebut menyebabkan partisipan masuk kedalam penjara dan ketika bebas partisipan ditinggal pergi oleh istri dan anaknya untuk menikah dengan orang lain.

Data yang peneliti dapatkan memiliki perbedaan dengan apa yang Prochaska \& DiClemente (1992) jelaskan mengenai tahap perubahan seseorang. Tahap perubahan pada partisipan tidak melalui tahap prakontemplasi namun langsung masuk kedalam tahap kontemplasi. Alasannya adalah karena pelaku kriminal menyadari bahwa perilakunya salah. Partisipan menyadari bahwa perilakunya yang lama merupakan perilaku yang salah. Keuntungan yang partisipan dapatkan yang menjadikan partisipan memilih bertahan dengan perilakunya yang lama.

Tahap kontemplasi Prochaska \& DiClemente (1992) merupakan tahap dimana seseorang menyadari kesalahan dalam perilakunya namun masih belum ada kemauan untuk melakukan perubahan. Hal ini terjadi karena masih adanya permasalahan untung rugi yang didapat dari perilaku yang saat ini ataupun ketika melakukan perubahan. Tahap ini merupakan tahap yang paling lama dalam proses perubahan seseorang.

Sejalan dengan partisipan yang memasuki tahap ini dimana tahap ini merupakan tahap yang paling lama dari proses perubahan partisipan. Partisipan memasuki tahap ini ketika partisipan dimasa remajanya hingga berusia lebih dari 20 tahun. Lamanya partisipan pada tahap ini karena partisipan masih merasa mencuri merupakan cara cepat dalam mendapatkan uang untuk memenuhi kebutuhan hidupnya dan bersenang-senang meskipun partisipan menyadari bahwa hal tersebut adalah salah.

Partisipan memasuki tahap persiapan ketika partisipan telah selesai menjalani hukumannya di Nusakambangan. Partisipan berniat untuk tidak mencuri lagi dan hal ini diperkuat oleh saat partisipan ingin membangun rumah tangga lagi. Istrinya saat ini bersedia dinikahi asalkan partisipan berhenti melakukan pencurian. Partisipan juga merasa sudah cukup dengan siksaan yang didapat didalam lapas. Faktor yang lain adalah karena dari nasehat salah satu kakak kandungnya yang meminta partisipan untuk berhenti demi keluarganya.

Tahap persiapan Prochaska \& DiClemente (1992) adalah individu mulai mengambil langkah awal dalam perubahan perilakunya, namun perubahan yang dilakukan tidak sepenuhnya dan masih menyisakan perilaku yang lama. Langkah awal perubahan yang partisipan lakukan adalah mulai bekerja serabutan seperti bekerja dibengkel, menarik becak dan menjadi pemulung. Partisipan juga merantau bersama istrinya hingga keluar pulau Jawa. Partisipan yang memasuki tahap ini meski sudah berhenti mencuri namun partisipan masih sering menerima ajakan temannya untuk mengkonsumsi alkohol serta gaya hidup yang negatif lainnya. 
Partisipan telah mempelajari perilaku yang baru untuk perubahannya. Perilaku yang diinginkan dalam proses perubahannya adalah berhenti dalam dunia kriminal dan dapat menolong orang lain. Keinginannya untuk menolong orang lain memiliki hubungan dengan pesan terakhir orangtua angkatnya sebelum meninggal dan merasa berhutang budi dengan orangtua angkatnya karena telah mengasuhnya selama berada di Surabaya. Keinginannya untuk menolong orang lain juga tidak terlepas dari partisipan yang merasa berdosa kepada Tuhan karena perilakunya dimasa lalu.

Partisipan memasuki tahap aksi ketika partisipan kembali menjalani masa hukuman di rutan Medaeng karena percobaan pembunuhan dan tuduhan pembakaran lapas. Partisipan terkena kasus percobaan pembunuhan karena partisipan membela diri tikaman pisau dari teman anaknya saat partisipan mencoba menghentikan pertengkaran anaknya dan teman anaknya. Selama berada di rutan Medaeng, partisipan semakin menguatkan tekadnya untuk mengubah diri sepenuhnya dan tekadnya dijadikan tato dipunggung partisipan dengan tulisan "Demi Anak dan Istriku Aku Rela Bertaubat Selamanya."

Tahap aksi milik Prochaska \& DiClemente (1992) menjelaskan bahwa tahap dimana individu mulai memodifikasi perilaku, kebiasaan atau lingkungannya dengan tujuan untuk mengubah secara keseluruhan. Partisipan semakin meningkatkan perubahannya dengan berhenti sepenuhnya dari perilaku yang lama. Partisipan juga meningkatkan perubahannya dengan berusaha mengubah lingkungan sosialnya. Usaha ini bertujuan untuk semakin menguatkan perubahan perilaku yang baru dan mencegah partisipan kembali keperilakunya yang lama.
.Partisipan mencoba merintis komunitas pengajian bapak-bapak sebagai usaha dalam mengubah lingkungan sosialnya. Usahanya dalam merintis menuai berbagai macam hambatan. Provokasi dari ketua RT yang mengajak warga lain untuk tidak percaya dengan partisipan. Provokasi dari warga lain juga muncul bahwa partisipan akan mengkorip dana pengajian untuk keperluan pribadi. Akibatnya banyak warga yang tidak percaya yang menjadikan usaha partisipan dalam merintis pengajian mengalami beberapa kali kegagalan. Kegagalan yang partisipan dapatkan menjadikan partisipan berputus asa.

Partisipan juga menjadikan keluarganya motivasi dalam proses perubahan dirinya. Motivasi tersebut menjadikan semangat partisipan saat partisipan menghadapi masa-masa sulit dalam proses perubahannya. Partisipan akan kembali mengingat keluarganya sebagai sumber kekuatan dan menjadikan keluarga sebagai alasan mengapa partisipan melakukan perubahan dirinya.

Dukungan keluarga membantu partisipan dalam menghadapi hambatan yang muncul. Dukungan keluarga membantu partisipan untuk tetap bangkit dalam mencoba keinginannya untuk merintis pengajian dilingkungannya. Nsanze (2007) menjelaskan faktor eksternal berupa dukungan dari orang lain yaitu teman dan keluarga meningkatkan kemungkinan mantan narapidana dalam melakukan proses perubahan. Hingga akhirnya partisipan berhasil dalam merintis pengajian ibu-ibu yang anggota awalnya adalah mantan wanita tunasusila.

Gambaran mengenai lingkungan sosial keluarga partisipan bisa terlihat bahwa keluarga partisipan mendukung dalam proses perubahan partisipan. Istri partisipan pada saat itu tidak hanya mendukung namun juga mempengaruhi partisipan sehingga meningkatkan niat partisipan untuk dapat berubah menjadi 
pribadi yang lebih baik. Begitu juga saat partisipan semakin memantapkan niatnya untuk mengubah dirinya secara keseluruhan, keluarganya juga membantu partisipan dalam proses perubahannya seperti memberikan dukungan dan mengingatkan partisipan agar tidak kembali ke perilakunya yang lama.

Lingkungan masyarakat partisipan bedasarkan data yang peneliti dapatkan bahwa partisipan berada didalam lingkungan yang kurang sehat. Awalnya daerah tempat tinggal partisipan sering menjadi tempat perjudian, prostitusi, narkoba, dan mabuk-mabukkan.

Masyarakat kurang mendukung partisipan dalam proses perubahannya ketika partisipan memasuki tahap aksi dimana partisipan mulai mengubah lingkungan sosialnya dengan membangun pengajian. Provokasi dari ketua RT dan sejumlah warga yang mempengaruhi warga lain dan menyebabkan munculnya ketidakpercayaan terhadap partisipan. Ketidakpercayaan itu mengakibatkan partisipan mengalami kegagalan dalam mencoba mengubah lingkungan sosialnya.

Komitmen yang kuat untuk melakukan perubahan inilah yang menjadikan partisipan semakin meningkatkan perubahan dirinya dan mengubah lingkungan sosialnya. Komitmen tersebut menjadikan partisipan semakin yakin pada dirinya untuk mengubah dirinya dan lingkungannya meskipun hambatan akan muncul. Partisipan menghadapi hambatan yang muncul dalam berbagai bentuk yaitu mulai menolak ajakan teman, tidak menyerah dalam melakukan perubahan serta meminta dukungan sosial dari keluarganya.

Keberhasilan partisipan dalam tahap 4 ditunjukkan dengan partisipan yang mengubah dirinya secara keseluruhan baik dari perilakunya dan kebiasaannya. Keberhasilan partisipan melalui tahap ini menjadikan partisipan otomatis memasuki tahap pemeliharaan yang ditandai partisipan yang semakin mengembangkan perubahan dirinya. Pengembangan ini diwujudkan dengan dengan membangun taman baca masyarakat, bimbingan belajar gratis, beasiswa SMP, dan kegiatan sosial lainnya

\section{Simpulan}

Hasil penelitian mengenai proses perubahan mantan narapidana residivis telah peneliti analisis pada pembahasan sebelumnya. Bedasarkan hasil analisis tersebut, maka dapat kita tarik kesimpulannya bahwa partisipan dalam proses perubahannya memiliki perbedaan dengan teori yang dikemukakan oleh Prochaska \& DiClemente (1992) mengenai 5 tahapan proses perubahan individu yaitu yaitu Prakontemplasi, Kontemplasi, Persiapan, Aksi, dan Pemeliharaan.

Data yang peneliti dapatkan menunjukkan bahwa partisipan pada proses perubahannya langsung memasuki tahap kontemplasi. Perbedaan yang terjadi karena pada partisipan sebenarnya telah menyadari bahwa perilakunya pada awalnya merupakan adalah salah. Partisipan menyadari perilakunya salah namun masih tetap bertahan karena masih mempertimbangkan untung-rugi yang didapat dari perilakunya saat ini.

Tahap kedua merupakan tahap yang paling lama dalam tahap perubahan partisipan. Alasannya adalah karena perilaku ini muncul dari partisipan memasuki usia remaja dan tetap bertahan ketika partisipan telah memasuki usia dewasa awal. Partisipan menyadari perilaku kriminal dan gaya hidupnya adalah salah, namun partisipan masih berfikir bahwa mencuri adalah cara yang cepat untuk menjadikan partisipan kaya. Tahap ini merupakan tahapan yang paling lama dalam proses perubahan partisipan karena tahap ini muncul saat partisipan pertama kali memasuki dunia kriminal ketika memasuki usia remaja hingga 
kemudian berkali-kali terkena hukuman dan terkahir masuk kedalam Nusakambangan selama 9.5 tahun atau ketika partisipan memasuki pertengahan usia 20 tahun.

Selepas dari lapas Nusakambangan dan menikah lagi merupakan peristiwa yang menyebabkan partisipan memasuki tahap tiga atau tahap aksi. Partisipan sudah mulai berhenti mencuri meskipun masih memiliki dorongan untuk mencuri dan gaya hidup yang negatif seperti berjudi ataupun mabuk-mabukkan. Partisipan sudah menunjukkan beberapa perubahan seperti mulai bekerja serabutan dan merantau bersama istrinya untuk memenuhi kebutuhan keluarganya.

Partisipan terkena kasus percobaan pembunuhan dan tuduhan pembakaran Rutan Medaeng saat menjalani hukumannya karena percobaan pembunuhan. Setelah bebas partisipan mulai bertekad untuk mengubah dirinya secara keseluruhan. Pada saat ini partisipan mulai memasuki tahap keempat atau tahap Aksi. Partisipan mulai menghindari dan menolak ajakan teman-temannya untuk mengkonsumsi minuman keras ataupun perilaku lainnya. Partisipan juga berusaha mengubah dirinya dengan cara membangun komunitas pengajian agar dapat mengubah lingkungannya.

Partisipan pada tahap aksi tidak berjalan mulus begitu saja, berbagai macam hambatan partisipan hadapi seperti mendapatkan provokasi yang menyebabkan banyak warga tidak percaya pada partisipan. Akibatnya ketidakpercayaan tersebut menyebabkan partisipan mengalami kegagalan dalam merintis komunitas pengajian dimasyarakatnya. Kegagalan yang menghadapi partisipan memunculkan rasa putus asa pada diri partisipan.

Peran keluarga cukup berpengaruh pada partisipan yang memasuki tahap aksi. Berbagai bentuk dukungan keluarga seperti mengingatkan dan melarang partisipan untuk kembali lagi mengkonsumsi minuman keras hingga memberikan dorongan saat partisipan mengalami rasa putus asa untuk mengubah masyarakatnya Dukungan keluarga memberikan pengaruh dalam keberhasilan partisipan untuk melewati tahap aksi ini.

Partisipan yang merasakan efek positif pada perubahan dirinya yang baru akan memasuki tahap kelima atau tahap pemeliharaan. Tahap kelima ini ditunjukkan dengan semakin berkembangnya diri partisipan terhadap perubahan diri partisipan. Partisipan menunjukkan perkembangannya dengan melalui semakin aktif partisipan dalam kegiatan sosial seperti membangun taman baca masyarakat, bekerjasama dengan berbagai yayasan dan kegiatan sosial lainnya.

\section{Daftar Pustaka}

Cohen, G. L., \& Sherman, D. K. (2014). The Psychology of Change: SelfAffirmation and Social Psychological Intervention. Annual Review of Psychology, $65 \quad$ (1) 333-363. California: Stanford University

Direktorat Jenderal Pemasyarakatan. (2014). Ditjen PAS - SMS Gateway System. Online smslap.ditjenpas.go.id. Diakses 20 Desember 2014
Jones, C. M. (2005). Genetic and Environmental Influences on Criminal Behavior. Personality Papers. Online. http://www.personalityresearch.org.

Diakses 17 Agustus 2014

Lamley, C. K., \& Mitchell, R. W. (2012). Narrative Inquiry: Stories Lived, Stories Told (1st ed.). S. D. Lapan, M. T. Quartaroli, \& F. J. Riemer, (Eds.), Qualitative Research. An Introduction 
to Methods and Designs. Research Methods for the Social Sciences (pp. 243-270). San Fransisco: Jossey-Bass.

Lee, T. (2012). Recidivism Hard To Shake For Ex-Offenders Returning Home To Dim Prospects. Online. http://www.huffingtonpost.com.

Diakses 30 Desember 2014

Lubkin, I. M., \& Larsen, P. D. (2006). Chronic Illness: Impact and Interventions $\left(6^{\text {th }}\right.$ ed.). London: Jones And Bartlett Publishers.

Muhlausen, D. B. (2010). The Second Chance Act: More Evaluations of Effectiveness Needed. Online. http://www.heritage.org. Diakses 30 Desember 2014.

Nsanze, C. F. (2007). The Ex-prisoners' Transition Processes Into Society. Disertasi. University Of Göteborg: Gothenburg. Online. https://gupea.ub.gu.se. Diakses 30 Desember 2014.
Nuraini, A., \& Ahmadi, D. (2005). Teori Penjulukan. MediaTor, 6 (2), 297-303. Online. download.portalgaruda.org. Diakses 20 November 2014

Olson, J. M. (1992). Psychological Barriers to Behavior Change. Canadian Family Physician , 38 (1), 309-3019. Online. https://www.ncbi.nlm.nih.gov. Diakses 20 November 2014

Prochaska, J. O., DiClemente, C. C., \& Nocross, J. C. (1992). In Search of How People Change. American Psychologist , 47 (9), 1102-1112. Online. https://www.ncbi.nlm.nih.gov. Diakses 20 November 2014

Russell, J., \& Russell, L. (2006). Change Basics. Alexandria: ASTD Press. 